\title{
Toward an Understanding of Critical Success Factors for Student-Athlete Mental Health and Wellness, Academic Success, and Athletic Performance at the NCAA Division III Level
}

\author{
Kristina Navarro, Ph.D. \\ Rutgers University \\ Lindsey Greviskes, Ph.D. \\ University of Wisconsin-Whitewater \\ Logan Edwards, Ph.D. \\ University of Wisconsin-Whitewater \\ Kelly Witte, Ed.D. \\ University of Wisconsin-Whitewater \\ Lily Pittelkow, M.S.E. \\ University of Wisconsin-Whitewater \\ Jenny Scherer, M.S.E. \\ University of Wisconsin-Whitewater
}

\begin{abstract}
Current athletic administrators are not only charged with overseeing programs that are critical to student-athletes' athletics success, but they must also be increasingly aware of resources to support success in student-athletes' academic and personal lives. In turn, this empirical study explored the needs of student-athletes, coaches, and administrators pertaining to mental health and wellness, academic success, and athletic performance at the NCAA Division III level. A total of 66 athletes, 17 coaches, and 20 administrators were surveyed to discover which athletic support services currently existed and were desired at their respective institutions. Implications and recommendations are presented for athletic administrators as they develop programmatic support for millennial student-athletes who experience heightened mental health and wellness challenges during the transition to college.
\end{abstract}

Keywords: student-athletes, support services, intercollegiate athletics, transition programs 


\section{Critical Success Factors for Student-Athlete Mental Health}

The modern commercialized expansion of college athletics and the subsequent development of a tumultuous and dichotomous student-athlete identity provides a necessary understanding for researchers to unpack how the student-athlete experience within the context of their own generation contributes to their sense of identity in college. The commercialization of college sport in American society continues to perpetuate developmental challenges for contemporary student-athletes (Thelin, 1994). Strange (2004) describes the seven defining characteristics of the "Millennial" generation - rule following, sheltered, confident, conventional, team-oriented, pressured, and high achieving - as a challenge to the standard conventions of development. The contemporary student has been described as "ambitious but directionless" because they possess an innate need to achieve, but an inadequate competence for how to do so independently - especially in relation to their Baby Boomer parents (Coomes \& DeBard, 2004; Strange, 2004). In turn, contemporary students are entering into college with a far lesser developed sense of independence than generations past. Millennials conform in order to reduce pressure on themselves i.e., fitting into a group/team (Coomes \& DeBard, 2004). As a result, the constant struggle to belong can result in enhanced mental turmoil for the contemporary student. Building from the innate psychological and development issues faced by millennial students, studentathletes often face an enhanced sense of struggle as they transition to campus (Comeaux \& Harrison, 2011).

\section{Challenges Facing Student-Athletes: Role Conflict}

Literature on the student-athlete experience suggests that student-athletes face additional psychosocial challenges while developing a sense of direction during the higher education experience. In addition, the dual role required of student-athletes to serve as both students and athletes throughout the college experience has produced great controversy regarding the concept of the student-athlete ideal in the higher education system (Miller \& Kerr, 2003).

Bronfenbrenner (1979) defines a role as "a specific set of activities expected of an individual, which are often identified by the use of labels" (p. 85). In today's higher education system, student-athletes often struggle to balance such roles as they are labeled as athletes first, andstudents second (Adler \& Adler, 1987; Broughton \& Neyer, 2001). The university expects student-athletes to perform in the classroom assuming the primary role of student (Lapchick, 2006). However, demands placed on student-athletes to perform in the athletic arena often lead these individuals to assume the primary role of athlete (Baille \& Danish, 1992; Miller \& Kerr, 2003). Subsequently, conflict between the roles of student and athlete can develop (Adler \& Adler, 1987).

While higher education systems endorse the intercollegiate student-athlete experience as a means for competing in sport while preparing for career fields, student-athletes may struggle to uphold this ideal student-athlete scenario due to psychosocial and institutional barriers of role conflict intensified at the Division I Power 5 level (Lapchick, 2006). There has been some discussion and debate on differences between Division I and Division III athletics with regard to student-athlete identity and role conflict. Division III athletes often feel an extra strain compared to their non-athlete counterparts, due to the demands of the athletics programs compared to other extracurricular activities, as well as missed leisure time activities that many other students 
experience (Cantor \& Prentice, 1996). From a sociological perspective, the difference between Division I and III athletic programs that may influence an athlete's perception of their role (Coakley, 2009). Division I programs often focus on generating revenue rather than focusing on academic and personal development as is done at the Division III level (Coakley, 2009). However, some researchers contend that athletes across divisions (I and III) experience role conflict similarly (Sturm, Feltz, \& Gilson, 2011). In fact, these researchers found that male athletes were more likely to identify more strongly with the role of athlete, while female athletes were more likely to identify strongly with their student role, regardless of their division affiliation.

The concept of role conflict further intensifies the debate as to whether undergraduate students benefit from or are hindered by specialized athletic department support services. Researchers continue to probe how current athletics and student affairs professionals may exacerbate these challenges for student-athletes, who often already experience pressure to perform in the classroom and on the playing field (Adler \& Adler, 1987). The existing literature suggests that student-athletes face both internal and external challenges during their college experiences as they construct lifelong career plans and balance roles as students and athletes (Comeaux \& Harrison, 2011). Given a demonstrated challenge for holistic support during the college experience, athletics departments are increasingly expected to provide a myriad of support services to support student-athlete holistic development (Barkley, Taliaferro, Baker, \& Garcia, 2018). This, in turn, presents a greater need for athletic department structured support service during the undergraduate student-athlete experience as millennial students leave the home environment and face enhanced pressure to perform in the athletic arena. The student-athlete, coach, and administrator perspective is critical to understanding how athletic professionals can best assist student-athletes as they transition to college and form a new sense of identity amidst rampant issues of mental health and wellness.

\section{Generation Z Student-Athletes}

Today coaches and administrators must also face additional challenges of supporting Generation Z student-athletes who continue to struggle with issues of mental health and wellness. All of these factors together have created a unique group which has indelibly posed significant challenges for student affairs, academic affairs, and athletics practitioners over the last 15 years (Strange, 2004). This is of specific interest to student-athlete development professionals, as research now illustrates the mental health and wellness challenges that student-athletes face during the transition to unstructured environments in college.

\section{Literature Review}

\section{Student-Athlete Mental Health and Sport Psychology in College}

College students in general (including student-athletes and non-athletes across all divisions) are reporting more anxiety and depression than ever. According to a 2017 study that surveyed 63,000 college students at 92 schools conducted by the American College Health Association (ACHA), 40\% of college students said they felt so depressed within the past 12 months that it was difficult for them to function. Sixty one percent reported feeling overwhelming anxiety. These results reflect the current mental health challenges of college students who are stressed due to facing new life transitions into unfamiliar environments, coupled with high performance 
expectations, academic and social pressures, and balancing classes, coursework, jobs, and social adjustments.

Concurrently, student-athletes face many unique challenges, pressures, and added stressors in their journey through college. In addition to taking a full load of classes and making time for studying and coursework, student-athletes also spend hours in daily practices and competition. These extensive time demands can play a significant role in the stress that student-athletes experience. Student-athletes attempt to balance the substantial time demands of collegiate academics, campus life, and intercollegiate athletics. They must devote time to practice on top of classroom work, as well as sustain pressures to achieve success, work through injuries, burn out, and conflict with teammates or coaches, etc. Collectively, these issues can pose problems that lead to increased occurrences of mental and physical exhaustion (Beauchemin, 2014). According to data from the National College Health Assessment surveys, about $31 \%$ of male and $48 \%$ of female National Collegiate Athletic Association (NCAA) student-athlete respondents from 92 different institutions reported either depression or anxiety symptoms each year of the 2008 and 2012 academic years due to the many aforementioned challenges and stressors (ACHA, 2018). A more recent study reports that of the approximately 400,000 NCAA student-athletes participating in sports at more than 1,000 member institutions across the United States (U.S.), rates of depression range $15.6 \%$ to $21.0 \%$, and freshman are at greater risk than other collegiate class years to develop depressive symptoms (Sudano, Collins, \& Miles, 2017). Evidence has also shown that due to the extensive time demands, pressures, and added stressors, collegiate athletes are at significant risk for other mental health related problems such as clinical or subclinical eating disorders, sleep disturbances, gambling addictions, substance abuse, mood disorders, and even suicide (Moreland, Coxe, \& Yang, 2017).

Moreover, both the Centers for Disease Control and Prevention (CDC; 2018) and the National Institute of Mental Health (NIMH; 2019) report that suicides in the U.S. are at their highest rate in 30 years, and currently, the second leading cause of death for this population (10-34 years of age). According to research released in 2015 by the Journal of Sports Health, NCAA male athletes have a significantly higher rate of suicide compared to female athletes, and football athletes appear to be at greatest risk. However, attitudes related to help-seeking and perceived stigma associated with counseling services by student-athletes continue to be significant barriers to accessing support. Many student-athletes perceive needing help as a sign of weakness (Birky, 2007). This attitude of invincibility, which especially plagues male student-athletes, combined with demanding time schedules, leads to hesitation and difficulty in seeking services/support for mental health issues and does not allow for early detection of problems (Beauchemin, 2014). Therefore, this can lead to depression and anxiety symptoms of increased severity that put student-athletes at risk for spiraling into major mental health crises such as panic attacks, self-harm, and/or suicide (Armstrong, Burcin, Bjerke, \& Early, 2015).

In particular, male student-athletes who participate in a sport that emphasizes masculinity, risk-taking, or physical contact are shown to have a stigma toward seeking a consultation with a sport psychologist (Martin, 2005). The same study hypothesized that modifying descriptors used with sport psychology to terms such as "mental toughness strategies" or "performance enhancement services" could help to overcome barriers for student-athletes who seek mental health services (Martin, 2005). Student-athletes may overcome the stigma associated with seeing a sport psychologist if the consult is framed around improving their athletic performance. 
Despite the growing population of student-athletes who can benefit from support of a sport psychologist, only $40 \%$ of NCAA Division I university athletic training rooms use screening instruments to assess student-athletes for mental health issues, i.e., depression, anxiety, eating disorders, substance use, mood disorders, and attention deficit hyperactivity (Sudano \& Miles, 2017). Some athletic trainers surveyed in a study reported that they lacked a formal mental health referral process inside their athletic department (Clement, Granquist, \& Arvinen-Barrow, 2013). This is typically due to a pattern of administrators reporting an inability-whether real or imagined - to provide collegiate athletes with dedicated mental health services geared toward the athlete (Moreland et al., 2017). Ultimately the organizational structure of the athletic program and the characteristics, attitudes, opinions, and behaviors of those close to the athlete will impact whether an athlete chooses to utilize mental health services (Moreland et al., 2017). Clearly, a need for additional support services is now present across Division I, II, and III institutions. The need for support services permeates each division, yet often is stifled due to budget constraints at lower divisions (Thelin, 1994). Division I institutions have larger budgets, and therefore, more human resources and support services for their students and athletes; however, according to a 2018 study by the Center for Collegiate Mental Health (CCMH, 2018), all U.S. colleges and universities are facing an unprecedented demand for counseling and mental health services, as students visiting counseling centers increased by $30 \%$ on average, while university enrollment grew by less than six percent. This reiterates that schools cannot keep up with the record numbers of college students seeking treatment for anxiety, depression, and the continued need for additional support services for all students across all divisions.

\section{Student-Athlete Identity Development}

In addition to mental health issues, student-athlete well-being is quickly moving to the forefront of the college athletics landscape. Student-athlete well-being goes beyond a successful athletic performance. Student-athlete well-being can be described as pertaining to an athlete's physical health, mental health, stigma, athletic performance, and self-care (Beauchemin, 2014). It is imperative for athletes to have an increased sense of well-being in order for them to flourish as both a student and an athlete. As previously discussed, many athletes are reluctant to seek help for mental health issues or any issue that may be a sign of weakness. Student-athletes may also struggle with drug abuse issues. In fact, Green and colleagues posit that abuse of alcohol, amphetamines, marijuana, and psychedelics are most common at the Division III level (Green, Uryasz, Petr, \& Bray, 2001).

Many student-athletes also struggle with their identity as a student-athlete. Over identification as an athlete can be detrimental to a student-athlete's academic, social, and personal development and, ultimately, to their sense of holistic wellness (Good, Brewer, Petitpas, Van Raalte, \& Mahar, 1993). The researchers go on to contend that for many student-athletes, much of their sense of being and purpose is connected to their identification with the athlete role. They view themselves as athletes first and students second. This over identification becomes especially problematic when student-athletes become injured or exhaust their collegiate eligibility. Interventions aimed at increasing student-athletes' interests, skills, values, beliefs, and career awareness can help broaden their life perspectives beyond the athletic arena (Shurts \& Shoffner, 2004). 
While little attention has been given to Division III athletes specifically, researchers have debated whether or not Division III athletes feel the same amount of strain to be successful in the athletic arena as their Division I counterparts. As previously mentioned, the revenue-generating focus of Division I programs compared to the academic and personal development focus of Division III programs may be influential to a student-athlete's identity (Coakley, 2009). Yet, other researchers have found that it seems to be gender, rather than division, that influences the development of student versus athlete identity (Sturm et al., 2011). Regardless of the differences between Division I and Division III with regard to athletic identity, there are various financial and programmatic constraints that place Division III programs at a disadvantage when it comes to student-athlete support services. For example, the lack of team physicians available to Division III student-athletes highlights the lack of resources often experienced by Division III institutions (LaRue, 2010). Furthermore, from a financial standpoint, Division III institutions that have higher overall operating budgets historically have won the most championships (Katz, Pfleegor, Schaeperkoetter, \& Bass, 2015). Ultimately, the financial situation of a program, particularly at the Division III level, contributes not only to a program's success athletically, but also in terms of the ability to provide student-athlete support services to enhance well-being and identity development.

\section{Student-Athletes and Mental Health Resources}

At the professional association level, the NCAA Best Mental Health Practices (2016) document states that mental health providers and general student support services should be easily accessible to student-athletes and should include multiple disciplines (e.g., athletic trainers, primary care physicians, licensed mental health providers, life skills support staff, registered dieticians, etc.). It may be assumed that use of such general support services is no higher due to lack of knowledge about integrated care and support services, lack of access to and availability of care and services, and stigma associated with mental health and illness and help-seeking behaviors, especially among student-athletes (Sudano et al., 2017).

One way to provide comprehensive care to student-athletes is first, using an integrated care and support services model approach (Sudano et al., 2017). The foundation of an ecological model is biopsychosocial and combines medical, mental, and behavioral health services to help studentathletes who present to primary care and tertiary care settings. The Mental Health Best Practices document (2016) suggests an increase in collaboration between mental health and physical care to provide comprehensive services to student-athletes, noting that a student-athlete's well-being is best served through: (a) a collaborative process in which the mental health provider(s) and life skills support staff are easily accessible and within or proximate to athletic department facilities; (b) an interdisciplinary team that consists of primary care and mental health providers, and; (c) an interdisciplinary team that reviews the medical care of student-athletes. Incorporating and presenting an ecological model approach into the athletic facilities, training room, department offices, etc., can provide coaches and student-athletes with knowledge and access to comprehensive care options available to them and may reduce stigma associated with mental health and illness and help-seeking behaviors (Sudano et al., 2017).

Mental health problems are as prevalent among college students as they are among sameaged non-students and appear to be increasing in number and severity (Eisenberg, Hunt, \& Speer, 2012; Hunt \& Eisenberg, 2010). Mental disorders account for nearly one-half of the disease burden 
for young adults in the United States, with onset of most lifetime mental disorders by age 24; suicide is the second leading cause of death for those between 18-24 years old (CDC, 2015; 2016). According to the mental health and help-seeking research, the majority of college students with a mental disorder(s) do not seek help when in need. Therefore, they do not receive appropriate care or treatment for such mental health issues, even though help-seeking is essential to their mental, physical, and social health and well-being over time (Eisenberg et al., 2012; Hunt \& Eisenberg, 2010). This lack of treatment seeking represents a missed opportunity for decreasing the burden of mental illnesses in these student/young-adult populations and is problematic because untreated mental health problems during college can have significant implications for academic success, productivity, substance use, and social relationships later in life (Blanco et al., 2008; Eisenberg et al., 2012).

These trends and consequences have led to calls for greater attention to the mental health of college students, and particularly student-athletes, since an abundance of literature in the field generally supports the claim that too often young people with mental health problems do not seek help when they are in mental-emotional distress (anxiety, depression) or suicidal, etc. (Eisenberg et al., 2012; Hunt \& Eisenberg, 2012). Therefore, there is an ongoing need to understand what may promote both college students' and student-athletes' mental health, athletic performance, and success in life during and after school and athletics.

Research suggests that NCAA student-athletes have higher levels of stress and other behavioral health issues, including substance use, than non-athletes (Sudano et al., 2017; Yang et al., 2007). Additionally, for several reasons, student-athletes may be less likely to admit to mental and/or behavioral health issues and seek mental health care. As previously mentioned, of the approximately 400,000 NCAA student-athletes participating in sports at more than 1,000 member institutions across the United States, rates of depression range $15.6 \%$ to $21.0 \%$, and freshman are at greater risk than other collegiate class years to develop depressive symptoms (Sudano et al., 2017; Yang et al., 2007). What's more, student-athletes negotiate both internal and external challenges during their experience in higher education as students and athletes (Comeaux \& Harrison, 2011). Student-athletes experience common mental health issues such as anxiety disorders, eating disorders, and substance use disorders (Yang et al., 2007).

Student-athletes also undergo stressors not experienced by other college students; these include extensive time demands, pressures to achieve, injuries, burn out, and conflict with teammates and coaches (Sudano et al., 2017). If left unaddressed, these stressors may lead to mental health issues, such as increased anxiety and/or depression. However, because of stigma associated with mental health and illness, fears that teammates, coaches, and administration may not be supportive, student-athletes may be less likely to acknowledge mental health issues and seek appropriate care (Eisenberg et al., 2012; Hunt \& Eisenberg, 2010; Sudano et al., 2017). Since collegiate-athletes are less likely than non-athlete peers to seek help for mental health problems, they may be at greater risk for suicide (Sudano et al., 2017).

When examining Division III athletes specifically, it is important to note that Division III is the largest division, with almost 100 more institutions than the Division I level. Moreover, at the Division III level, research by the NCAA (2017) has shown that athletes spend just as much time on academics and athletics combined as Division I athletes, leading to similar levels of stress and demands but without the same number of support resources. The lack of athletic department 
resources at the Division III level often leads to student-athletes being referred to general mental health practitioners that do not have specific training to assist the athletic population (LaRue, 2010). These trends express the need for the desire of more offered support services at the NCAA Division III level for mental health and wellness, as well as academic and career support.

\section{Student-Athlete Academic Success}

As the over identification with the role of athlete continues to be an issue in college athletics, student-athletes demonstrate struggles to successfully navigate academic choices and pathways in college. As early as the 1970s, it was first highlighted how certain time demands during the intercollegiate experience can present barriers to student-athletes as they identify their choice of major in college (Renick, 1974). As early as 1975, it was suggested that student-athletes struggled in the Division I system specifically to explore, choose, and prepare for meaningful careers due to an inability to identify major choices that complemented their interests and strengths (Purdy, Eitzen, \& Hufnagel, 1982; Spivey \& Jones, 1975). More recently, researchers continue to show that student-athletes experience barriers in the current higher education system to choose and prepare for meaningful career fields as they struggle academically with the transition to college (Case, Greer, \& Brown, 1987; Comeaux \& Harrison, 2011; Fountain \& Finley 2009; 2011; Knobler, 2007). In addition, researchers suggest student-athletes struggle to dedicate sufficient time and resources to further academic and postgraduate plans (Blann, 1985; Comeaux \& Harrison, 2011; Kennedy \& Dimmick, 1987; Sowa \& Gressard, 1983. This lack of time dedicated to academic and career exploration and the role of student can result in a lower perceived level of career maturity upon graduation (Comeaux \& Harrison, 2011; Fountain \& Finley, 2011; Kennedy \& Dimmick, 1987; Sowa \& Gressard, 1983). Due to an inability to balance roles as student and athlete, identity struggles continue to exacerbate academic development as student-athletes transition to college; this negatively influences personal, social, and academic success.

\section{Student-Athlete Athletic Performance}

While the majority of aforementioned topics focus on dilemmas student-athletes face pertaining to student success as they navigate daily life in college, these individuals are still expected to perform as high-profile athletes. The large focus placed on winning and athletic success often exacerbates power dynamics between coaches and student-athletes (Spivey \& Jones, 1975). Ultimately, these researchers posit that the commercialization of athletics across divisions coupled with power dynamics between coaches and athletes inhibits meaningful preparation for life after sport for some students as they focus ultimately on athletic performance. This warrants further exploration to understand just how student-athletes construct career plans and in what ways higher education practitioners may help or hinder this process.

Currently, most athletic departments include a sports medicine or athletic training staff to address injuries and other physical needs of the athletes (National Strength and Conditioning Association [NSCA], 2018). Similarly, over the past decade, it has become commonplace to employ strength and conditioning or sport performance coaches to oversee the non-technical and non-tactical portions of physical training (NSCA, 2018). While these resources are an important part of a holistic student-athlete experience, it is clear that additional support systems are needed to promote long-term success for student-athletes. 


\section{Purpose and Significance of Study}

Building from the identified issues of role conflict that student-athletes face as they transition to college, few researchers have explored how athletic departments can best support NCAA Division III student-athletes with respect to mental health and wellness, academic success, and sport performance. To better understand how NCAA Division III athletic departments support the mental health and wellness needs of contemporary student-athletes, we approached this study as a 360-degree needs assessment from the perspective of student-athletes, coaches, athletic department administration, and staff. In turn, the purpose of this study was to understand if NCAA Division III athletic departments supported our literature findings that both physical and mental support services should exist on campus for contemporary student-athletes. Secondly, we specifically sought to understand if discrepancies existed between current mental health and wellness resources/services and desired mental health and wellness resources/services offered as identified by three stakeholder groups: (a) student-athletes, (b) coaches, and c) administration and athletic department staff.

\section{Methodology}

\section{Theoretical Framework}

To frame this study, the researchers draw on Astin's (1984) theory of student involvement. This theory is widely utilized within the current student affairs literature, yet is rarely applied to the student-athlete higher education population subset. To further understand how students grow and develop during college, Astin considers how undergraduate students interact with their campus environments upon transitioning from high school. This theory presents a modern interpretation of numerous developmental theories in higher education. Astin (1984) posits that the level of physical and psychological energy that students devote to the academic experience during transition ultimately influence levels of personal development and learning. Furthermore, he argues students' commitment to physical and psychological components of the college experience occur along a continuum. The quantity and quality of students' interactions with campus outlets influence levels of personal development, identity development, balance, and holistic learning.

According to Astin (1999), students who are actively involved both physically and psychologically during the college experience demonstrate greater overall balance in learning and personal development. This study draws on the major tenets of Astin's (1984) theory to understand how the student-athlete experience influences student development and adjustment to college. We draw on this theory to quantify and qualify the educational benefits of the support services that assist student-athletes as they develop strategies to cope with mental health and wellness. In addition, we draw on this theory to help identify how student affairs practitioners can best support student-athletes cognitively and psychologically as they are expected to perform dual roles as students and athletes. This theory provides a lens to understand how, if at all, current levels of campus and athletic department support assist student-athletes who cope with mental health and wellness. Finally, this theory provides a lens for how coaches, administrators, and student affairs professionals can best support the psychosocial developmental needs for contemporary studentathletes. 


\section{Description of Sample Selection}

The sample for the current study includes three different participant groups: athletes, coaches, and administration/athletic department staff. The demographic details for the three groups are outlined below.

Student-athletes. The sample size for the athlete group was originally 113 , but after screening and cleaning the data, only 66 participants provided complete datasets. There were 44 females and 21 males with a class distribution as follows: 25 freshmen, 23 sophomores, 9 juniors, 8 seniors. Participants reported the following with regard to their eligibility status: 27 - 1st year, 23 - 2nd year, 8 - 3rd year, 7 - 4th year. The following sports were represented in the sample: Baseball (3), Men's Cross-Country (1), Football (5), Men's Soccer (4), Men's Track and Field (3), Wrestling (2), Women's Basketball (7), Women's Bowling (1), Women's Cross-Country (3), Women's Golf (8), Women's Gymnastics (1), Women's Soccer (4), Softball (3), Women's Swim and Dive (2), Women's Track and Field (14), Women's Volleyball (3), Men's Ice Hockey (1), Women's Lacrosse (1), Men's Gymnastics (2), Men's Water Polo (1).

Coaches. The total sample size for the coach group was 24; however, after screening and cleaning the data, only 17 coaches provided complete datasets. The sample included 10 males and 7 females with a mean age of 35.7. Coaches reported the following with regard to ethnicity: White/Caucasian - 16, Black/African American - 1. The following titles were held by sample members: head coach (10), associate head coach (2), assistant coach (9), graduate assistant (1). The coaches had a mean of 6.9 years in their current coaching positions with a minimum of 1 and maximum of 16 years, while their total number of years involved in intercollegiate athletics was a mean of 11.4 with a minimum of 1 and maximum of 34 years. Most coaches held a master's degree (14), while others held a bachelor's degree (4). A total of 15 coaches reported being former intercollegiate athletes. The following sports were represented in the coaching sample: Baseball, Men's Cross-Country, Football, Men's Soccer, Men's Tennis, Men's Track and Field, Wrestling, Women's Basketball, Women's Cross Country, Women's Golf, Women's Gymnastics, Women's Soccer, Women's Track and Field, Women's Volleyball, Women's Tennis.

Administration/athletic department staff. The total sample size for the administration and athletic department staff was 26 , but after screening and cleaning the data, only 20 participants provided complete datasets. The sample consisted of 13 males and 7 females with a mean age of 41.4. The following was reported with regard to ethnicity: White/Caucasian - 18, Hispanic/Latino - 1, Black/African American - 1. The sample consisted of 5 athletic directors, 12 athletic trainers/sports medicine staff members, 3 sport performance/strength and conditioning staff members, and 4 other administrative positions. The participants reported holding their current positions for an average of 8.6 years with minimum of 1 year and a maximum of 28. Participants reported being involved in intercollegiate athletics in any position for a mean of 19.1 years with a minimum of 4 and a maximum of 35. Most participants held a master's degree (18), while one individual held a PhD and one individual held a professional doctorate (i.e., MD, DPT, or Other). Ten participants reported being former intercollegiate athletes. The administration and athletic department staff group reported offering the following sports at their respective institutions: Baseball, Men's Basketball, Men's Cross-Country, Football, Men's Soccer, Men's Swim and Dive, Men's Tennis, Men's Track and Field, Wrestling, Women's Basketball, Women's Bowling, 
Women's Cross-Country, Women's Golf, Women's Gymnastics, Women's Soccer, Softball, Women's Swim and Dive, Women's Track and Field, Women's Volleyball, Women's Tennis, Women‘s Ice Hockey, Men's Ice Hockey, Women's Lacrosse, Men’s Lacrosse, Rowing.

\section{Research Design and Data Collection}

Procedures. To conduct our study, we used a survey methodology to assess the current psychosocial resources and/or services available to NCAA Division III student-athletes as well as the desired resources and services. In addition to surveying student-athletes, researchers surveyed current athletic administrators and coaches that provide support services for student-athletes. The survey instrument was developed by the researchers in order to understand which support services are available to student-athletes and which services are desired by student-athletes, coaches, and administrators. The survey asked participants to "Read the following list of resources/services and respond to all THREE of the following statements." The three statements were as follows: "My athletic department currently offers this resource/service," "I wish my athletic department currently offered this resource/service OR I am glad my athletic department currently offers this resource/service," "I have used or plan to use the following resource/services." All three could be answered with the options "Yes," "No," or "Unsure." The list of resources was generated from examination of the services offered at several NCAA Division I, II, and III institutions in order to form an exhaustive list of potential services.

Entry. We developed a Qualtrics survey instrument focusing on the three areas of interest: mental health and wellness support services, academic support service, and athletic performance support services. The survey was distributed via e-mail to student-athlete listservs in a Midwest Division III conference provided by the athletic departments within the body of a recruitment email. Survey language clearly articulated that participation was voluntary and had no bearing on their athletic or academic standing. The survey remained open for a period of two weeks with one reminder e-mail correspondence.

Data analysis. We exported all Qualtrics survey data to excel. In turn, we cleaned and screened exported files for missing or incomplete data. From this data file, we calculated frequencies and descriptive statistics to analyze the current needs of college student-athletes, coaches, and administrators.

Ethical considerations. To ensure the privacy and rights of all participants in this study, we reminded participants that participation was completely voluntary and had no bearing on athletic participation. Coaches were not informed of participation and the names of student-athletes were known only by the specific members of the university athletic academic support staff who assisted with the collection of sample population data. These individuals were asked to keep all information confidential. Finally, all interview protocols received IRB approval prior to any human subject interaction. 


\section{Findings}

The data collected from participants were analyzed by calculating descriptive statistics and frequency values. Several findings with regard to our hypotheses are outlined in the tables below. Table 1 displays the responses from each participant group (student-athletes, coaches, and administration/staff) with regard to which services or resources are currently available at their respective Division III NCAA institutions.

Table 1

Resources and Services Currently Provided at Participants' Institutions

\begin{tabular}{|c|c|c|c|c|}
\hline \multirow[t]{2}{*}{ Resource or Service } & \multirow[t]{2}{*}{ Participant Group } & \multicolumn{3}{|c|}{ Response } \\
\hline & & Yes & No & Unsure \\
\hline \multirow[t]{3}{*}{ Athletic Training/Sports Medicine } & Student-Athletes & $95 \%$ & $0 \%$ & $2 \%$ \\
\hline & Coaches & $94 \%$ & $0 \%$ & $5 \%$ \\
\hline & Administration/Staff & $100 \%$ & $0 \%$ & $0 \%$ \\
\hline \multirow{3}{*}{$\begin{array}{c}\text { Sport Performance/Strength and } \\
\text { Conditioning }\end{array}$} & Student-Athletes & $92 \%$ & $0 \%$ & $6 \%$ \\
\hline & Coaches & $94 \%$ & $0 \%$ & $5 \%$ \\
\hline & Administration/Staff & $90 \%$ & $10 \%$ & $0 \%$ \\
\hline \multirow{3}{*}{$\begin{array}{c}\text { Student-Athlete } \\
\text { Development/Leadership Training }\end{array}$} & Student-Athletes & $74 \%$ & $2 \%$ & $23 \%$ \\
\hline & Coaches & $83 \%$ & $11 \%$ & $5 \%$ \\
\hline & Administration/Staff & $70 \%$ & $25 \%$ & $5 \%$ \\
\hline \multirow{3}{*}{$\begin{array}{c}\text { Athletic Department Academic } \\
\text { Advisors }\end{array}$} & Student-Athletes & $51 \%$ & $24 \%$ & $21 \%$ \\
\hline & Coaches & $44 \%$ & $44 \%$ & $11 \%$ \\
\hline & Administration/Staff & $25 \%$ & $65 \%$ & $10 \%$ \\
\hline \multirow[t]{3}{*}{ Athlete Specific Tutoring } & Student-Athletes & $55 \%$ & $20 \%$ & $23 \%$ \\
\hline & Coaches & $67 \%$ & $28 \%$ & $6 \%$ \\
\hline & Administration/Staff & $25 \%$ & $50 \%$ & $25 \%$ \\
\hline \multirow{3}{*}{$\begin{array}{l}\text { Sport Psychology Services (aimed at } \\
\text { performance Enhancement) }\end{array}$} & Student-Athletes & $36 \%$ & $26 \%$ & $35 \%$ \\
\hline & Coaches & $17 \%$ & $61 \%$ & $22 \%$ \\
\hline & Administration/Staff & $15 \%$ & $85 \%$ & $0 \%$ \\
\hline \multirow{2}{*}{$\begin{array}{l}\text { Mental Health Counseling (Within } \\
\text { the athletic department) }\end{array}$} & Student-Athletes & $29 \%$ & $33 \%$ & $35 \%$ \\
\hline & Coaches & $6 \%$ & $78 \%$ & $11 \%$ \\
\hline
\end{tabular}




\begin{tabular}{|c|c|c|c|c|}
\hline & Administration/Staff & $0 \%$ & $95 \%$ & $5 \%$ \\
\hline \multirow{3}{*}{$\begin{array}{c}\text { Mental Health Counseling } \\
\text { (provided to general student } \\
\text { population) }\end{array}$} & Student-Athletes & $83 \%$ & $5 \%$ & $9 \%$ \\
\hline & Coaches & $83 \%$ & $11 \%$ & $0 \%$ \\
\hline & Administration/Staff & $95 \%$ & $5 \%$ & $0 \%$ \\
\hline \multirow{3}{*}{$\begin{array}{l}\text { Student-Athlete Well-Being } \\
\text { Education }\end{array}$} & Student-Athletes & $47 \%$ & $18 \%$ & $32 \%$ \\
\hline & Coaches & $44 \%$ & $44 \%$ & $6 \%$ \\
\hline & Administration/Staff & $55 \%$ & $35 \%$ & $10 \%$ \\
\hline \multirow{3}{*}{$\begin{array}{l}\text { Faculty Athletic Representative } \\
\text { (FAR) }\end{array}$} & Student-Athletes & $42 \%$ & $6 \%$ & $48 \%$ \\
\hline & Coaches & $83 \%$ & $6 \%$ & $6 \%$ \\
\hline & Administration/Staff & $95 \%$ & $5 \%$ & $0 \%$ \\
\hline \multirow[t]{3}{*}{ Equipment Management/Services } & Student-Athletes & $48 \%$ & $15 \%$ & $33 \%$ \\
\hline & Coaches & $61 \%$ & $28 \%$ & $6 \%$ \\
\hline & Administration/Staff & $75 \%$ & $25 \%$ & $0 \%$ \\
\hline \multirow[t]{3}{*}{ Laundry Services } & Student-Athletes & $91 \%$ & $0 \%$ & $6 \%$ \\
\hline & Coaches & $89 \%$ & $6 \%$ & $0 \%$ \\
\hline & Administration/Staff & $85 \%$ & $15 \%$ & $0 \%$ \\
\hline \multirow[t]{3}{*}{ Athlete Cafeteria } & Student-Athletes & $23 \%$ & $64 \%$ & $11 \%$ \\
\hline & Coaches & $0 \%$ & $89 \%$ & $6 \%$ \\
\hline & Administration/Staff & $0 \%$ & $100 \%$ & $0 \%$ \\
\hline \multirow[t]{3}{*}{ Nutritionist/Registered Dietician } & Student-Athletes & $80 \%$ & $3 \%$ & $14 \%$ \\
\hline & Coaches & $39 \%$ & $39 \%$ & $17 \%$ \\
\hline & Administration/Staff & $35 \%$ & $65 \%$ & $0 \%$ \\
\hline \multirow{3}{*}{$\begin{array}{l}\text { Freshmen Transition } \\
\text { Program/Course }\end{array}$} & Student-Athletes & $67 \%$ & $12 \%$ & $18 \%$ \\
\hline & Coaches & $78 \%$ & $6 \%$ & $11 \%$ \\
\hline & Administration/Staff & $60 \%$ & $20 \%$ & $20 \%$ \\
\hline \multirow{3}{*}{$\begin{array}{c}\text { Graduation/Career Transition } \\
\text { Program }\end{array}$} & Student-Athletes & $36 \%$ & $18 \%$ & $41 \%$ \\
\hline & Coaches & $33 \%$ & $50 \%$ & $11 \%$ \\
\hline & Administration/Staff & $30 \%$ & $55 \%$ & $15 \%$ \\
\hline
\end{tabular}


Table 2 compares the current reported services/resources available for student-athletes to the desired services/resources for all three participant groups.

Table 2

Available Services Compared to Desire for Services

\begin{tabular}{|c|c|c|c|}
\hline \multirow[t]{2}{*}{ Resource or Service } & \multirow[t]{2}{*}{ Participant Group } & \multirow{2}{*}{$\begin{array}{c}\begin{array}{c}\text { Availability of } \\
\text { service }\end{array} \\
\text { Yes }\end{array}$} & \multirow{2}{*}{$\begin{array}{c}\begin{array}{c}\text { Desire for } \\
\text { service }\end{array} \\
\text { Yes }\end{array}$} \\
\hline & & & \\
\hline \multirow[t]{3}{*}{ Athletic Training/Sports Medicine } & Student-Athletes & $95 \%$ & $80 \%$ \\
\hline & Coaches & $94 \%$ & $94 \%$ \\
\hline & Administration/Staff & $100 \%$ & $100 \%$ \\
\hline \multirow{3}{*}{$\begin{array}{c}\text { Sport Performance/Strength and } \\
\text { Conditioning }\end{array}$} & Student-Athletes & $92 \%$ & $81 \%$ \\
\hline & Coaches & $94 \%$ & $94 \%$ \\
\hline & Administration/Staff & $90 \%$ & $100 \%$ \\
\hline \multirow{3}{*}{$\begin{array}{c}\text { Student-Athlete } \\
\text { Development/Leadership Training }\end{array}$} & Student-Athletes & $74 \%$ & $71 \%$ \\
\hline & Coaches & $83 \%$ & $94 \%$ \\
\hline & Administration/Staff & $70 \%$ & $90 \%$ \\
\hline \multirow{3}{*}{$\begin{array}{c}\text { Athletic Department Academic } \\
\text { Advisors }\end{array}$} & Student-Athletes & $51 \%$ & $71 \%$ \\
\hline & Coaches & $44 \%$ & $89 \%$ \\
\hline & Administration/Staff & $25 \%$ & $75 \%$ \\
\hline \multirow[t]{3}{*}{ Athlete Specific Tutoring } & Student-Athletes & $55 \%$ & $68 \%$ \\
\hline & Coaches & $67 \%$ & $94 \%$ \\
\hline & Administration/Staff & $25 \%$ & $70 \%$ \\
\hline \multirow{3}{*}{$\begin{array}{l}\text { Sport Psychology Services (aimed at } \\
\text { performance Enhancement) }\end{array}$} & Student-Athletes & $36 \%$ & $71 \%$ \\
\hline & Coaches & $17 \%$ & $94 \%$ \\
\hline & Administration/Staff & $15 \%$ & $80 \%$ \\
\hline \multirow{3}{*}{$\begin{array}{l}\text { Mental Health Counseling (Within } \\
\text { the athletic department) }\end{array}$} & Student-Athletes & $29 \%$ & $73 \%$ \\
\hline & Coaches & $6 \%$ & $94 \%$ \\
\hline & Administration/Staff & $0 \%$ & $65 \%$ \\
\hline
\end{tabular}




\begin{tabular}{|c|c|c|c|}
\hline \multirow{3}{*}{$\begin{array}{l}\text { Mental Health Counseling } \\
\text { (provided to general student } \\
\text { population) }\end{array}$} & Student-Athletes & $83 \%$ & $73 \%$ \\
\hline & Coaches & $83 \%$ & $100 \%$ \\
\hline & Administration/Staff & $95 \%$ & $90 \%$ \\
\hline \multirow{3}{*}{$\begin{array}{c}\text { Student-Athlete Well-Being } \\
\text { Education }\end{array}$} & Student-Athletes & $47 \%$ & $71 \%$ \\
\hline & Coaches & $44 \%$ & $100 \%$ \\
\hline & Administration/Staff & $55 \%$ & $90 \%$ \\
\hline \multirow{3}{*}{$\begin{array}{c}\text { Faculty Athletic Representative } \\
\text { (FAR) }\end{array}$} & Student-Athletes & $42 \%$ & $62 \%$ \\
\hline & Coaches & $83 \%$ & $94 \%$ \\
\hline & Administration/Staff & $95 \%$ & $95 \%$ \\
\hline \multirow[t]{3}{*}{ Equipment Management/Services } & Student-Athletes & $48 \%$ & $61 \%$ \\
\hline & Coaches & $61 \%$ & $88 \%$ \\
\hline & Administration/Staff & $75 \%$ & $85 \%$ \\
\hline \multirow[t]{3}{*}{ Laundry Services } & Student-Athletes & $91 \%$ & $74 \%$ \\
\hline & Coaches & $89 \%$ & $100 \%$ \\
\hline & Administration/Staff & $85 \%$ & $90 \%$ \\
\hline \multirow[t]{3}{*}{ Athlete Cafeteria } & Student-Athletes & $23 \%$ & $55 \%$ \\
\hline & Coaches & $0 \%$ & $82 \%$ \\
\hline & Administration/Staff & $0 \%$ & $40 \%$ \\
\hline \multirow[t]{3}{*}{ Nutritionist/Registered Dietician } & Student-Athletes & $80 \%$ & $70 \%$ \\
\hline & Coaches & $39 \%$ & $100 \%$ \\
\hline & Administration/Staff & $35 \%$ & $85 \%$ \\
\hline \multirow{3}{*}{$\begin{array}{l}\text { Freshmen Transition } \\
\text { Program/Course }\end{array}$} & Student-Athletes & $67 \%$ & $64 \%$ \\
\hline & Coaches & $78 \%$ & $77 \%$ \\
\hline & Administration/Staff & $60 \%$ & $80 \%$ \\
\hline \multirow{3}{*}{$\begin{array}{c}\text { Graduation/Career Transition } \\
\text { Program }\end{array}$} & Student-Athletes & $36 \%$ & $70 \%$ \\
\hline & Coaches & $33 \%$ & $83 \%$ \\
\hline & Administration/Staff & $30 \%$ & $85 \%$ \\
\hline
\end{tabular}


As outlined below in Table 3, margins of more than $50 \%$ existed between availability of resources and desire of sport psychology and mental health counseling resources within the athletics department.

Table 3

Discrepancy in Resources and Desires: Sport Psychology and Mental Health Counseling

\begin{tabular}{|c|c|c|c|}
\hline \multirow[t]{2}{*}{ Resource or Service } & Participant Group & $\begin{array}{c}\text { Availability of } \\
\text { service }\end{array}$ & $\begin{array}{c}\text { Desire for } \\
\text { service }\end{array}$ \\
\hline & Yes & Yes & \\
\hline \multirow{3}{*}{$\begin{array}{l}\text { Sport Psychology Services (aimed at } \\
\text { performance Enhancement) }\end{array}$} & Student-Athletes & $36 \%$ & $71 \%$ \\
\hline & Coaches & $17 \%$ & $94 \%$ \\
\hline & Administration/Staff & $15 \%$ & $80 \%$ \\
\hline \multirow{3}{*}{$\begin{array}{l}\text { Mental Health Counseling (Within } \\
\text { the athletic department) }\end{array}$} & Student-Athletes & $29 \%$ & $73 \%$ \\
\hline & Coaches & $6 \%$ & $94 \%$ \\
\hline & Administration/Staff & $0 \%$ & $65 \%$ \\
\hline
\end{tabular}

\section{Discussion}

Overall, findings demonstrate that there is a clear gap in the desired and offered support services at the NCAA Division III level for mental health and wellness, as well as academic and career support. The findings support the need to further explore the multiple critical success factors for student-athlete mental health and well-being, academic success, and athletic performance. Building from the innate psychosocial and development issues (i.e., identity and role conflicts) faced by millennial students, student-athletes often face an enhanced sense of struggle as they transition to campus (Comeaux \& Harrison, 2011). Literature on the student-athlete experience suggests that student-athletes face additional psychosocial challenges while developing a sense of direction during the higher education experience and are in clear need of support services. One major topic implicated throughout these findings is the mental health of college students, and particularly student-athletes as a growing public health concern.

Some important features of Table 1 include the high percentage of participants in all groups that indicated physical services were provided at their institution, such as athletic training/sports medicine and sport performance/strength and conditioning. Conversely, fewer participants reported that their institutions provided mental and social services, such as sport psychology, mental health counseling, leadership training, and wellness education. Additionally, based on responses, academic support seemed to be lacking. Some large discrepancies noted in Table 2 include: athletic academic advisors, sport psychology, mental health counseling offered within the athletic department, well-being education, athlete cafeteria, nutritionist/dietician, and graduate transition program. 
Results from this study indicate a clear discrepancy between mental health and wellness services available and desired levels of resources among all three groups of student-athletes, coaches, and administration/staff. Most surprising in this study was the fact that while both coaches and student-athlete concurred that there was a drastic lack for mental health support services for the unique needs of student-athletes, coaches were most adamant that additional resources were necessary. As identified in Table 2, 36\% of student-athletes were aware of sport psychology resources existing, but $71 \%$ desired more resources. This margin was even larger for coaches as $17 \%$ were aware of current resources but $94 \%$ desired more resources. In addition, administration and staff noted that $0 \%$ of resources existed for mental health and counseling, but $80 \%$ desired more resources within athletics.

From Table 3, it is clear that coaches demonstrate a higher desire for additional resources to support mental health and wellness. In turn, it is inferred coaches specifically see the daily struggles and possess a heightened level of awareness of individual student-athletes' struggles. While administrators and staff also cite a general awareness of additional resources, coaches have day-to-day contact with student-athletes. These data as a whole demonstrate a marked need to explore ways in which the athletic department can best support student-athletes not only on campus, but internal to the athletics department via a holistic ecological model.

\section{Implications for Student-Athlete Development Professionals}

At the campus level, hiring and/or including a mental health and life skills support staff who share a vision with the coaches, athletic trainers, and administrators is critical to the success of an integrated/ecological behavioral health program. In addition, the mental health and life skills support provider(s) should be familiar with the cultures of college-age individuals, and of studentathletes and athletics in particular. In addition, modifying operations and establishing protocols, procedures, and documentation consistent with NCAA and specific university policies are important steps to take before launching an integrated/ecological framework/model of support and behavioral health program. It is important to consider barriers to increasing the integration of care may include, such as, physical space, organizational infrastructure, and other institutional and human resources factors.

Finally, these data support the characteristics of Millennial and Generation Z studentathletes who are a self-identified demographic of individuals who are rule following, sheltered, confident, conventional, team-oriented, pressured, and high achieving. This is evidenced by the fact that student-athletes desired additional resources both internal and external to the athletics department to support their mental health and wellness needs as they transition to an unstructured college environment. Student-athlete development professionals can utilize this information to help build support programs internal to athletics and form strategic partnerships with campusbased organizations to best support Millennial and Generation Z student-athletes. 


\section{Implications for Campus Programming}

While this study suggests that coaches and administrators desire additional support services for student-athletes, the NCAA still does not formally mandate or measure the presence of psychological or mental health programming at the Division III level. However, to date, the National Association of Academic Advisor for Athletics (N4A) has recently made strides to support the psychosocial and holistic development for individuals who work specifically with student-athletes with the inception of a rebrand and retool of its mission statement (N4A, 2017). This organization now formally referred to as the National Association for Academic Advisors and Student-Athlete Development professionals demonstrates an industry-wide approach to holistically supporting the multifaceted psychosocial and developmental needs of student-athletes. Moving forward, student affairs professionals may consider actively participating in this association, which focuses on providing resources for student-athletes in transition who experience issues with role conflict, identity development, and mental health.

\section{Limitations and Future Research}

As this was a pilot study, one limitation is that survey validation was not included in this study. This study reflects the in-depth personal experiences of individuals attending Division III institutions and findings cannot be widely generalized beyond the specific environment in which the study was conducted. However, findings can suggest areas for future inquiry at similar size institutions.

Researches must continue to understand how to best support student-athletes as they transition to college. A student-athlete's mental health and physical health status must be considered equally important, and such a philosophy and culture requires acceptance by both the coaching and medical staff (Sudano et al., 2017). However, building and sustaining a college culture that values student-athlete mental health and well-being can be difficult. In turn, an ecological care and support services model that represents the full-range of services within a collegiate setting may be challenging without a framework or conceptual model to facilitate knowledge of support services that are available. Researches must continue to explore how to best depict holistic support services including mental health and wellness, academic success, athletic performance, and positive attitudes towards mental health and help-seeking behaviors. Moreover, researchers would be well-advised to conduct pre-and-post survey questionnaires of model incorporation into the collegiate setting to determine significant changes in knowledge of support services, access to and availability of support services, utilization of those support services, and changes in stigma and attitudes towards seeking help for mental and/or behavioral health issues.

To best measure and implement holistic programs, researchers must identify how to best establish a conceptual framework and model. Important steps in establishing a conceptual framework/model include first, building an interdisciplinary support team, reviewing and revising protocols to increase integration of care and support, modifying documentation practices, and creating a plan for program evaluation, as there is a need for program evaluation of integrated/ecological support services models in sports medicine settings (Sudano et al., 2017). 
Evaluation should include quantitative analysis of clinical outcomes (e.g., Patient Health Questionnaire-9, General Anxiety Disorder-7), operational (e.g., the student-athlete shows rates for mental health appointments through integrated care services vs. referral to the university's counseling center), and financial (e.g., hospitalization, missed practices, and games). Finally, indepth interviews with student-athlete development professionals to explore the student-athlete's experience of integrated care should be conducted to assess student-athlete satisfaction and improve an integrated care program within a collegiate setting.

\section{Conclusions}

In summation, this study supports two major findings in the research: (a) student-athletes struggled to balance multiple roles and, (b) in turn, athletic professionals must provide enhanced support services. Given the demonstrated challenge for holistic support during the college experience, the formation of an integrated support services team and a coinciding ecological framework/model of support services may be helpful for meeting the needs of student-athletes and athletics departments. A visual model could best support departments that are increasingly expected to provide a myriad of structured services to support student-athlete holistic development (Barkley et al., 2018). The perspectives of student-athletes, coaches, and administrators alike are critical to understanding how athletic administrators can best assist student-athletes as they transition to college and form a balanced sense of identity amidst widespread mental health and wellness issues. 


\section{References}

Adler, P., \& Adler, P. (1987). Role conflict and identity salience: College athletics and the academic role. Social Science Journal, 24(2), 443-450.

American College Health Association. (2018). American College Health Association-National College Health Assessment II: Reference Group Executive Summary Fall 2017. Hanover, MD: American College Health Association.

Armstrong, S.N., Burcin, M.M., Bjerke, W., \& Early, J. (2015). Depression in student-athletes: A particularly at-risk group? A systematic review of the literature. Athletic Insight, 7(2), 177-193.

Astin, A.W. (1984). Student involvement: A developmental theory for higher education. Journal of College Student Personnel, 25, 297-308.

Astin, A.W. (1999). Student involvement: A developmental theory for higher education. Journal of College Student Development, 40(5), 518-529.

Baille, P.H.F., \& Danish, S.J. (1992). Understanding the career transition of athletes. Sport Psychologist, 6, 77-98.

Barkley, L., Taliaferro, L.A., Baker, K., \& Garcia, J. (2018). The holistic athletic healthcare model: Addressing the developmental, social, and cultural needs of collegiate athletes. Journal of Higher Education Athletics \& Innovation, 1(3), 26-47.

Beauchemin, J. (2014). College student-athlete wellness: An integrative outreach model. College Student Journal, 48(2), 268-280.

Birky, I. (2007). Counseling student-athletes: Sport psychology as a specialization. In J.A. Lippincott \& R.B. Lippincott (Eds.), Special populations in college counseling, pp. 2135. Alexandria, VA: American Counseling Association.

Blanco, C., Okuda, M., Wright, C., Hasin, D., Grant, B., Liu, S., \& Olfson, M. (2008). Mental health of college students and their non-college-attending peers: Results from the National Epidemiologic Study of Alcohol and Related Conditions. Archives of General Psychiatry, 65(12), 1429-1437.

Blann, F. W. (1985). Intercollegiate athletic competition and students' educational and career plans. Journal of College Student Personnel, 26(2), 115-18.

Bronfenbrenner, U. (1979). The ecology of human development. Cambridge, MA: Harvard University Press.

Broughton, E., \& Neyer, M. (2001). Advising and counseling student-athletes. New Directions for Student Services, 93, 47-53. 
Cantor, N.E., \& Prentice, D.A. (1996, March). The life of the modern-day student-athlete: Opportunities won and lost. Paper presented at the Princeton Conference on Higher Education, Princeton University, Princeton, NJ.

Case, B., Greer, S., \& Brown, J. (1987). Academic clustering in athletics: Myth or reality? Arena Review, 11(2), 48-56.

Center for Collegiate Mental Health (CCMH - 2018). Retrieved from https://ccmh.psu.edu/files/2019/04/2018-Annual-Report-4.15.19-FINAL-1s1dzvo.pdf

Centers for Disease Control and Prevention (2018). Retrieved from https://www.cdc.gov/vitalsigns/suicide/index.html

Centers for Disease Control and Prevention-Adolescent and School Health (2016). Retrieved from https://www.cdc.gov/healthyYouth/data/yrbs/index.htm

Centers for Disease Control and Prevention-Mental Health. (2015). Retrieved from http://www.cdc.gov/mentalhealth/

Clement, D., Granquist, M.D., \& Arvinen-Barrow, M.M. (2013). Psychosocial aspects of athletic injuries as perceived by athletic trainers. Journal of Athletic Training, 48, 512-21.

Coakley, J. (2009). Sport and society: Issues and controversies. (10th ed.). New York: NY, McGrawHill.

Comeaux, E. \& Harrison, C.K. (2011). A conceptual model of academic success for studentathletes. Educational Researcher, 40(5), 235-245.

Coomes, M.D., \& DeBard, R. (Eds.). (2004). Serving the Millennial Generation: New Directions for Student Services, Number 106 (Vol. 68). Hoboken, NJ: John Wiley \& Sons.

DeBard, R. (2004). Millennials coming to college. New Directions for Student Services, 106, 33 45 .

Eisenberg, D., Hunt, J., \& Speer, N. (2012). Help-seeking for mental health on college campuses: Review of evidence and next steps for research and practice. Harvard Review Psychiatry, 20(4), 222-232.

Fountain, J.J., \& Finley, P.S. (2009). Academic majors of upperclassmen Football Players in the Atlantic Coast Conference: An Analysis of Academic Clustering Comparing White and Minority Players, Journal of Issues in Intercollegiate Athletics, 2, 1-13.

Fountain, J.J., \& Finley, P.S. (2011). Academic clustering: A longitudinal analysis of Division I football programs, Journal of Issues in Intercollegiate Athletics, 4, $24-21$.

Good, A.J., Brewer, B.W., Petitpas, A., Van Raalte, J., \& Mahar, M. (1993). Identity foreclosure, athletic identity and college sport participation. Academic Athletic Journal, 8, 1-12. 
Green, G.A., Uryasz, F.D., Petr, T.A., \& Bray, C.D. (2001). NCAA study of substance use and abuse habits of college student-athletes. Clinical Journal of Sport Medicine, 11, 51-56.

Hunt, J., \& Eisenberg, D. (2010). Mental health problems and help-seeking behaviors among college students. Journal of Adolescent Health, 46, 3-10.

Katz, M., Pfleegor, A.G., Schaeperkoetter, C., \& Bass, J. (2015). Factors for success in NCAA Division III athletics. Journal of Issues in Intercollegiate Athletics, 8, 102-122.

Kennedy, S.R., \& Dimick, K.M. (1987). Career maturity and professional sports expectations of college football and basketball players. Journal of College Student Personnel, 27, 548559.

Knobler, M. (2007). Athletes choose majors to accommodate sports. Atlanta Journal Constitution, 1,1 .

Lapchick, R. E. (2006). New Game Plan for College Sport. Westport: Praeger Publishers.

LaRue, M.J. (2010). The role of certified athletic trainers in the recognition and referral of mental health issues in intercollegiate student-athletes. Retrieved from the University of Minnesota Digital Conservancy, http://hdl.handle.net/11299/100230.

Martin, S.B. (2005). High school and college athletes' attitudes toward sport psychology consulting. Journal of Applied Sport Psychology, 17(2), 127-139.

Miller, P.S., \& Kerr, G.A. (2003). The role experimentation of intercollegiate student-athletes. The Sport Psychologist, 17, 196-219.

Moreland, J.J., Coxe, K.A., \& Yang, J. (2017). Collegiate athletes' mental health services utilization: A systematic review of conceptualizations, operationalizations, facilitators, and barriers. Journal of Sport and Health Science, 7, 58-69.

N4A. (2017). National Association of Academic Advisors for Athletics N4A mentoring program. Retrieved from http://www.nacda.com/nfoura/mentoringprogram.html

National Collegiate Athletic Association (NCAA). (2017). Sports Science Institute. Retrieved from http://www.ncaa.org/sport-science-institute

National Institute of Mental Health. (2019). Retrieved from https://www.nimh.nih.gov/health/statistics/suicide.shtml

National Strength and Conditioning Association. (2018). National Strength and Conditioning Association. Retrieved from https://www.nsca.com/

NCAA Mental Health Best Practices. (2016). National Collegiate Athletic Association. Retrieved from http://www.ncaa.org/sport-science-institute/mental-health 
Purdy, D. A., Eitzen, D. S., \& Hufnagel, R. (1982). Are athletes also students? The educational attainment of college athletes. Social Problems, 29(4), 439-448.

Renick, J. (1974). The use and misuse of college athletics. The Journal of Higher Education, 45(7), 545-552.

Shurts, W.M., \& Shoffner, M.F. (2004). Providing career counseling for collegiate studentathletes: A learning theory approach. Journal of Career Development, 31(2), 95-109.

Sowa, C., \& Gressard, C. (1983). Athletic participation: Its relationship to student development. Journal of College Student Personnel, 24, 236-239.

Spivey, D., \& Jones, T.A. (1975). Intercollegiate athletic servitude: A case study of the Black Illinois student-athlete. Social Science Quarterly, 54, 939-947.

Strange, C.C. (2004). Constructions of student development across the generations. New Directions for Student Services, 106, 47-57.

Sturm, J., Feltz, D., \& Gilson, T. (2011). A comparison of athlete and student identity for Division I and Division III athletes. Journal of Sport Behavior, 34(3), 295.

Sudano, L.E., Collins, G., \& Miles, C.M. (2017). Reducing barriers to mental health care for student-athletes: An integrated care model. Families, Systems, \& Health, 35, 77-84.

Thelin, J.R. (1994). Games colleges play: Scandal and reform in intercollegiate athletics. Baltimore, MD: John Hopkins University Press.

Yang, J., Peek-Asa, C., Corlette, J.D., Cheng, G., Foster, D.T., \& Albright, J. (2007). Prevalence of and risk factors associated with symptoms of depression in competitive collegiate student-athletes. Clinical Journal of Sport Medicine, 17(6), 481-487. 